\title{
マルハナバチ逃亡防止のためのネット展張技術 一ネットの種類とハチが通り抜けできない間隙幅
}

\author{
小出哲哉・山田佳廣*・矢部和則・山下文秋
}

Tetsuya Koide, Yoshihiro Yamada*, Kazunori Yabe and Fumiaki Yamashita: Characteristics of netted greenhouses for containing bumblebees: types of netting and maximum width of joint gaps

\section{Summary}

Nets that have meshes of $4 \times 4 \mathrm{~mm}$ or less that do not slip are suitable for adding to greenhouses designed to contain bumblebees. Some types of net need to be stretched tightly to avoid escapes. The width of joint gaps in greenhouses should be no more than $3.0 \mathrm{~mm}$.

\section{緒言}

マルハナバチはトマトの授粉用昆虫として注目され, わが国に拈いても1991年以来，外来種のセイヨウオオマ ルハナバチ (Bombus terrestris Linnaeus)（以下セイヨウ) が利用されてきた。セイヨウの使用量は2003年にはおよ そ7 万群にも及び（光畑・和田，2005），トマトを中心 に 3,600 ha 以上で利用されている（農水省, 2005）。し かし，施設から逃げ出したセイヨウの野生巣が相次いで 発見されていることから, セイヨウの野外定着の可能性 が強く示唆されている（鷲谷，1998；中島ら，2004; 村 松ら，2004）。セイヨウが定着することによる在来の種 及び群集に及ぼす悪影響が指摘されている(松村・熟谷, 2002 ; 五箇, 1998，2000)。そのためセイヨウは2005年 12 月特定外来生物に指定され，2006年 9 月から法律によ り輸入，飼育，運搬等が規制されるに至った。セイヨウ を農業分野で使うためには, 施設開口部にネットを張り, 逃亡防止を図った上で，環境大臣の許可を得なければな らない。しかし，2005年末の時点では，セイヨウの逃亡 防止を保証するネット展張技術が確立していない。

筆者らはネット展張のセイヨウ逃亡防止に対する一連 の検証を行っている。その一環として，この論文では市 販のネットの素材, 目の大きさ, 張り方がセイヨウの逃 亡防止に及ぼす影響を調べるため, 実験的に各種ネット を張った箱に巣箱を入れ，逃亡の程度を調べた。また， 温室には扉や煙突周りなどに必ず間隙ができるが，その 間隙を幅何 mm 以下に抑えればセイヨウが逃亡できな
くなるかを実験的に確かめた。

本文に入るに先立ちマルハナバチと防虫ネットを提供 いただいた各会社（第 1,3 表参照）及び国立環境研究 所に深謝申し上げる。なお本研究は，先端技術を活用し た農林水産研究高度化事業「授粉用マルハナバチの逃亡 防止策と生態リスク管理技術の開発プロジェクト」の一 環として遂行されたものである。

\section{材料および方法}

\section{1. 市販ネットの逃亡防止効果}

目合いや特性の違う13種のネットを供試した（第 1 表)。マルハナバチ用ネットは目合い $2 \times 2 \mathrm{~mm}$ よりも きいものであるが，実用場面ではマルハナバチ逃亡防止 と防虫用を兼悋て目合い $2 \mathrm{~mm}$ 以下のネットも使用され ていることから，これらのネットも用いた。実験は2005 年 8 月17日から10月23日にかけて順次行った。

セイヨウ (アピ (株)）の巣箱を，供試ネットを張っ た箱 $(70 \times 80 \times 105 \mathrm{~cm})$ に入れ，さらにその箱を目合い $1 \times 1 \mathrm{~mm}$ のダイオサンシャイン S2000(ダイオ化成(株)) を張った箱 $(90 \times 80 \times 120 \mathrm{~cm})$ に入れ，八チの行動を観 察した。また, ネットの引っ張り強度がマルハナの通り 抜け率に及湆す影響を調査するため, 各種ネットについ て，ネットをきつく張った区（タイト区）とゆるく張っ た区（ルーズ区）を同時に設け，各区に 1 巣を入れた。 放飼期間は原則として合計 4 日間とし，放飼八千数の体 サイズによる影響を除くため，放飼 2 日後にタイト区と

愛知県農業総合試験場・*三重大学大学院生物資源学研究科 Aichi Agricultural Research Center; *Graduate School of Bioresources, Mie University 2007年 2 月 26 日受理 
第 1 表 供試ネット

\begin{tabular}{|c|c|c|c|c|c|c|c|}
\hline 商品名 & 会社 & 目合い & 材質 & 透光率\% & 色 & 目ずれ & 織り方 \\
\hline 日石マルハナネット & 新日石プラスト（株） & $4 \times 4 \mathrm{~mm}$ & ポリエチレン & データ無 & 黒 & しない & 押し出しネット \\
\hline ライトネット & チッソ（株） & $4 \times 4 \mathrm{~mm}$ & $\begin{array}{l}\text { ポロプロピレン } \\
\text { ポリエチレン }\end{array}$ & $97-99$ & 透明 & しない & 熱融着 \\
\hline マルハナネット FC-4 & クラレトレーディング（株） & $4 \times 4 \mathrm{~mm}$ & ポリエチレン & 95 & 透明 & しない & 熱融着 \\
\hline マルハナバチネット & ダイオ化成（株） & 約 $3 \times 5 \mathrm{~mm}$ & ポリエチレン & 96 & 透明 & しやすい & カラミ織 \\
\hline サンサンはちネット & 日本ワイドクロス（株） & $3.6 \times 3.6 \mathrm{~mm}$ & ポリエチレン & 95 & 透明 & しない & 熱融着カラミ織 \\
\hline ダイオネット防風網140 & ダイオ化成（株） & $4 \times 4 \mathrm{~mm}$ & ポリエチレン & 遮光24 & 青 & しない & ラッセル編 \\
\hline サンサンネット & 日本ワイドクロス（株） & $2 \times 2 \mathrm{~mm}$ & ポリエチレン & 92 & 透明 & しない & カラミ織 \\
\hline ダイオネット防風網130 & ダイオ化成（株） & $2 \times 2 \mathrm{~mm}$ & ポリエチレン & 遮光 27 & 白 & しない & ラッセル編 \\
\hline ダイオサンシャイン & ダイオ化成（株） & $1 \times 1 \mathrm{~mm}$ & ポリエチレン & 約 90 & 透明 & しやすい & 平織 \\
\hline すくすくネット & シーアイ化成（株） & $\begin{array}{c}0.4 \mathrm{~mm} \\
(0.2 \sim 0.4 \mathrm{~mm})\end{array}$ & ポリエステル & 63.4 & 白 & しにくい & リップ織 \\
\hline ラューサンンサンネット & 日本ワイドクロス（株） & $0.4 \times 0.4 \mathrm{~mm}$ & ポリエチレン & 82 & 透明 & すぐする & 平織 \\
\hline ライトネット & チッソ（株） & $0.4 \times 0.4 \mathrm{~mm}$ & $\begin{array}{l}\text { ポロプロピレン } \\
\text { ポリエチレン }\end{array}$ & - & 透明 & しない & 熱融着 \\
\hline サンシャインソフト & ダイオ化成（株） & $0.4 \times 0.4 \mathrm{~mm}$ & ポリエチレン & 約 86 & 透明 & すぐする & 平織 \\
\hline
\end{tabular}

ルーズ区の巣箱を入れ替えた。実験開始時，同じ巣箱を 各種供試ネットの実験に使用したが，巣から出るハチは 時間がたつと減少したため，ネット内で飛翔するハチが 15 頭を越えるように 8 月 26 日，9月16日，10月 6 日に新 しい巣箱に換えた。実験は $24 \sim 26^{\circ} \mathrm{C}$ の恒温室内で行い, 日長は空からの自然日長と 6 時から 18 時までは $37 \mathrm{w}$ と $18 \mathrm{w}$ の蛍光灯で補光した。夜に乾燥花粉約 $10 \mathrm{~g}$ を巣箱 内に入れた。

\section{2. 通り抜けできない間隙の幅}

巣の入り口に間隙を設け，その間隙幅を変えた時の通 り抜けた個体の頭幅を計った。巣箱内に居る働きバチの 頭幅の頻度分布を知るため全個体の頭幅を測定した。

\section{間隙幅と通り抜け個体の頭幅の関係}

供試虫としてアリスタ・ライフサイエンス（株）のセ イヨウを用いた。測定対象物に接する向かい合ったノギ スの金属板部分 $(150 \mathrm{~mm})$ に縦 $20 \mathrm{~mm} \times$ 横 $150 \mathrm{~mm} \times$ 厚み $0.5 \mathrm{~mm}$ のアクリル板を取り付け， 2 枚のアクリル 板で間隙をつくり，その間隙幅を自由に調整できるよう にした（第 1 図）。巣箱の巣門外側に $5 \times 5 \times 25 \mathrm{~cm}$ の箱 を取り付け，上面に $3 \times 15 \mathrm{~cm}$ の穴を開けた。その穴の 上に上述のアクリル板を置き，アクリル板の間隙を通過 した個体の頭幅を測定した。通過個体が 5 分待っても出 ない場合は間隙幅を $0.1 \mathrm{~mm}$ ずつ広げた。

\section{働きバチの頭幅}

供試虫としてセイヨウの巣箱 6 箱中の個体を用いた (アピ（株），アリスタライフサイエンス（株），東海物 産（株）各社 2 箱ずつ)。巣箱到着後直ちに巣箱内にい る働きバチ全ての個体の頭幅をノギスで測定した。

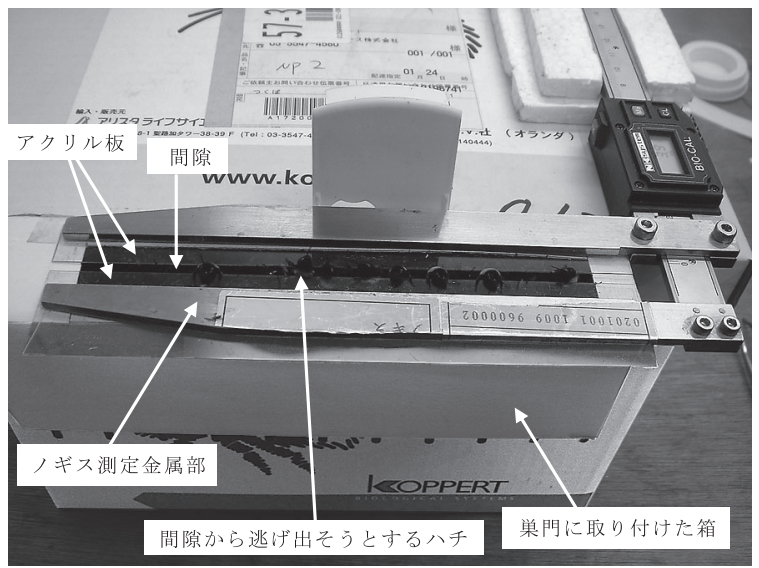

第1図 アクリル板付きノギスを取り付けた巣箱

\section{結果 \\ 1. 市販ネットの逃亡防止効果 \\ ネットの種類別の通り抜けと噛み切られの結果を第 2} 表に示した。セイヨウが通り抜けられたネットは日石マ ルハナネットとマルハナネット FC-4, ダイオネット防 風網140であった。マルハナバチネットは目ずれなしに 展張することができず，その目ずれからセイヨウが通過 した。その他のネットをセイヨウは通り抜けできなかっ た。また日石マルハナネットはタイト区とルーズ区によ る差は見られなかったが，マルハナネット FC-4，ダイ オネット防風網140ではゆるく張った時に通過個体が多 かった。各種ネットを通り抜けた個体の最大頭幅はマル ハナネット FC-4 は $3.44 \mathrm{~mm}$, 日石マルハナネットは 2.83 $\mathrm{mm}$ ，ダイオネット防風網140はルーズ区 $3.17 \mathrm{~mm}$ タイト 
小出哲哉・山田佳廣・矢部和則・山下文秋：マルハナバチ逃亡防止ネットの種類とハチが通り抜けできない間隙幅

第 2 表 ネットの種類と張り方別に示した通り抜け個体数と噛み切られの有無

\begin{tabular}{|c|c|c|c|c|}
\hline 商品名 & 調査月日 ${ }^{a}$ & 張り方 & 通り抜け個体数 & 噛み切られ \\
\hline \multirow{2}{*}{ 日石マルハナネット } & \multirow{2}{*}{9 月 $8 \sim 12$ 日 } & タイト & 1 & 無 \\
\hline & & ルーズ & 1 & 無 \\
\hline \multirow{2}{*}{ ライトネット } & \multirow{2}{*}{8 月17〜23日 } & タイト & 0 & 無 \\
\hline & & ルーズ & 0 & 有 $^{b}$ \\
\hline \multirow{2}{*}{ マルハナネット FC-4 } & \multirow{2}{*}{8 月26〜29日 } & タイト & 1 & 有 \\
\hline & & ルーズ & 4 & 有 \\
\hline \multirow{2}{*}{ マルハナバチネット } & \multirow{2}{*}{8 月 30 日〜 9 月 2 日 } & タイト & 0 & 無 \\
\hline & & ルーズ & $7^{\mathrm{c}}$ & 無 \\
\hline \multirow{2}{*}{ サンサンはちネット } & \multirow{2}{*}{9 月 $4 \sim 7$ 日 } & タイト & 0 & 無 \\
\hline & & ルーズ & 0 & $\begin{array}{l}\text { 無 } \\
\end{array}$ \\
\hline \multirow{2}{*}{ ダイオネット防風網140 } & \multirow{2}{*}{ 10月19～23日 } & タイト & 0 & 無 \\
\hline & & ルーズ & 2 & 無 \\
\hline \multirow{2}{*}{ サンサンネット } & \multirow{2}{*}{9 月 28 日 10 月 2 日 } & タイト & 0 & 無 \\
\hline & & ルーズ & 0 & 無 \\
\hline \multirow{2}{*}{ ダイオネット防風網130 } & \multirow{2}{*}{ 10月 $6 \sim 9$ 日 } & タイト & 0 & 無 \\
\hline & & ルーズ & 0 & 無 \\
\hline \multirow{2}{*}{ ダイオサンシャイン S2000 } & \multirow{2}{*}{ 10月10～13日 } & タイト & 0 & 無 \\
\hline & & ルーズ & 0 & 無 \\
\hline \multirow{2}{*}{ すくすくネット } & \multirow{2}{*}{9 月15～18日 } & タイト & 0 & 無 \\
\hline & & ルーズ & 0 & 有 \\
\hline \multirow{2}{*}{ ラューサンサイトンット } & \multirow{2}{*}{9 月24～27日 } & タイト & 0 & 無 \\
\hline & & ルーズ & 0 & 無 \\
\hline \multirow{2}{*}{ ライトネット } & \multirow{2}{*}{9 月20～23日 } & タイト & 0 & $\begin{array}{l}\text { 無 } \\
\end{array}$ \\
\hline & & ルーズ & 0 & $\begin{array}{l}\text { 無 } \\
\end{array}$ \\
\hline \multirow{2}{*}{ サンシャインソフト N4440 } & \multirow{2}{*}{ 10月14～17日 } & タイト & 0 & 無 \\
\hline & & ルーズ & 0 & $\begin{array}{l}\text { 無 } \\
\end{array}$ \\
\hline
\end{tabular}

a 試験期間は原則 4 日間であるが，4 日以上行った場合もある。

b 5 日目に噛み切られた。

c 展張時の目ずれによって通り抜けた。

区 $2.95 \mathrm{~mm}$ であった。

噛み切られたネットはマルハナネット FC-4 とすくす くネットの 2 種類であった。どちらも 4 日目に噛み切ら れ，その穴からハチが逃亡した。ライトネットは５日目 に噛み切られた。すくすくネットとライトネットはルー ズ区で噛み切られた。

\section{2. 通り抜けできない間隙の幅}

間隙幅と通り抜け個体の頭幅の関係

間隙幅と頭幅には強い相関 $(r=0.936, P<0.0001)$ が 見られた（第 2 図）。

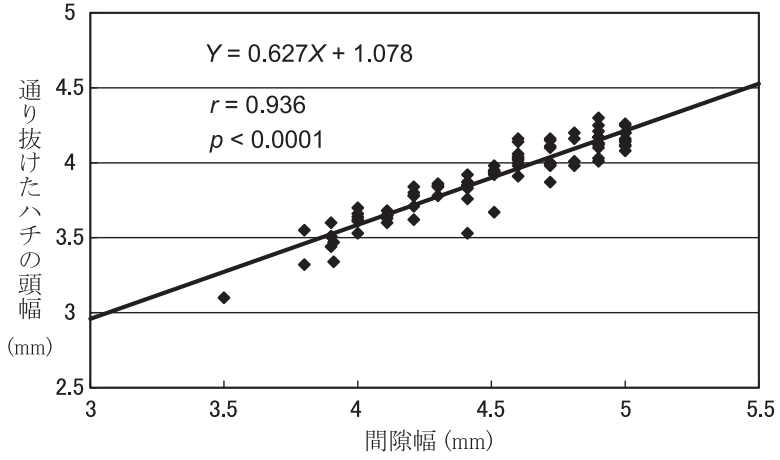

第2 図 間隙幅と通り抜けた働きバチの頭幅の関係 
第 3 表＼cjkstart働きバチの頭幅（mm）

\begin{tabular}{clccccc}
\hline 巣箱 ID & 提供会社 & 平均值 & 標準偏差 & 最小 & 最大 & $n$ \\
\hline 1 & アピ (株) & 3.41 & 0.14 & 2.99 & 3.90 & 118 \\
2 & アピ (株) & 3.64 & 0.26 & 3.01 & 4.28 & 167 \\
3 & 東海物産 (株) & 3.92 & 0.29 & 3.20 & 4.41 & 155 \\
4 & 東海物産 (株) & 3.81 & 0.26 & 2.99 & 4.47 & 146 \\
5 & アリスタライフサイエンス (株) & 4.21 & 0.25 & 3.21 & 4.69 & 127 \\
6 & アリスタライフサイエンス (株) & 4.05 & 0.28 & 3.16 & 4.65 & 211 \\
全部 & - & 3.86 & 0.35 & 2.99 & 4.69 & 924 \\
\hline
\end{tabular}

a 巣間で平均值に有意な差があった（Kruskal-Wallis test, $P<0.0001)$

\section{働きバチの頭幅}

働きバチの頭幅と八チ数を第 3 表に示した。巣間で働 きバチの平均頭幅に有意な差が見られた（Kruskal-Wallis test, $P<0.0001) 。 1$ 巣を除いて標準偏差はほぼ同じで, 平均值が大きくなるにつれて最小值最大值も増加した。 6 箱の働きバチは合計924頭で頭幅平均 $3.86 \mathrm{~mm}$ であっ た。最小頭幅は $2.99 \mathrm{~mm}$ ，最大は $4.69 \mathrm{~mm}$ であった。

\section{考察}

市販ネットを通り抜けた最大の個体は頭幅 $3.44 \mathrm{~mm}$ であった。この大きさは働きバ千では小さいほうである が，巣によっては平均サイズである（第 3 表）。マルハ ナバチでは，巣内の大きな個体は外役バチ，小さな個体 は内役バチとなる傾向がある（Free and Butter，1959； Cumber, 1949 ; Brian, 1952 ; Sakagami, 1976)。こ れ らのことから，ネットの目あいについては $4 \times 4 \mathrm{~m}$ 以下 であれば，大きな個体を多く含む巣では外役バチが通り 抜ける可能性は低く，実用上は問題ないと思われる。今 回アピ（株）提供のセイヨウが小さかった原因は，アピ （株）によると，飼育用の輸入花粉の一時的品質低下に よるらしい。通常こういったことは稀と思われるが，市 販セイヨウにおいても, 飼育条件によって小型個体が含 まれる可能性を否定できない。使用する前に，働き蜂の 大きさを調べ，小さいときは使用を控えるのが得策であ る。あるいは, 小型個体を含む巣の頻度が多い場合は, $4 \times 4 \mathrm{~m}$ 未満の目あいのネットの使用が望まれる。

また，噛み切られたネットが一部見られたが，これは 狭い空間に 4 日間閉じ込めての試験であったため, 同じ 箇所を長時間噛み続けて切られたものと考えられる。温 室での利用では同じ箇所を長時間にわたって噛み続けら れることは考えにくく，実用上は問題ないと思われる が，用心のため網系は太いものを使用すべきである。一 方，ネット展張時に目ずれが起きたネットがあった。目 ずれが起きないように気をつけて張っても目ずれを防ぐ ことができず，目ずれした箇所からハチの逃亡が見られ
た。これらのことから, 逃亡防止用ネットは $4 \times 4 \mathrm{~mm}$ 以下の目合いで, 熱融着もしくはラッセル織りなどの目 ずれしないネットを選ぶことが大切であることが明らか となった。また, 一部のネットはゆるく張った場合, 逃 亡を許した。このようなネットでは, 張り方に注意を払 う必要がある。

本試験における働きバチの頭幅の最小は $2.99 \mathrm{~mm}$ で あった。第 2 図の直線回帰式に頭幅 $2.99 \mathrm{~mm}$ を当ては めると, 間隙幅は $3.05 \mathrm{~mm}$ である。このことから, 逃 亡防止のため施設内の間隙の幅は $3 \mathrm{~mm}$ 以下にすべきと 結論づけた。

\section{摘 要}

マルハナバチ用逃亡防止ネットは, $4 \times 4 \mathrm{~mm}$ 以下の 目合いで目ずれしないネットを選ぶべきである。そして, ネットによってはきつく張る必要がある。施設内の接合 部の隙間は幅 $3.0 \mathrm{~mm}$ 以下に抑えるべきである。

\section{引用文献}

1) Brain, A. D. (1952) J. Anim. Ecol. 21: 223-240.

2) Cumber, R. A. (1949) Trans. R. Ent. Soc. Lond. 100: 1-45.

3) Free, J. B. and Butler (1959) Bumblebees. Collins, London, pp. 45-47.

4）五箇公一（1998）日本生物地理学会会報 53 ：91-101.

5）五箇公一 (2000) 応動昆 $44: 47-50$.

6）光烟雅宏・和田哲夫（2005）植物防疫 59 : 305-309.

7）松村千鶴・鷲谷いづみ（2002）保全生態学研究 $7: 39-50$.

8）松村千鶴・中島真紀・横山 潤・鷲谷いづみ（2004）保全 生態学研究 $9: 93-101$.

9）中島真紀・松村千鶴・横山 潤・熟谷いづみ（2004）保全 生態学研究 $9: 57-63$.

10）農林水産省生産局野菜課（2005）園芸用ガラス室・ハウス 等の設置状況 $207 \mathrm{p}$.

11) Sakagami, S. F. (1975) J. Fac. Sci. Hokkaido Univ. Zool. (VI Zool.) 3: 390-447.

12）熟谷いずみ（1998）日生態会誌 $48: 73-78$. 